4. Влияние препарата Простатилен® АЦ на фрагментацию ДНК сперматозоидов при лечении пациентов с хроническим абактериальным простатитом и сопутствующими нарушениями репродуктивной функции / С. Ю. Боровец и др. // Андрология и генитальная хирургия. 2017. № 3. C. 54-58.

DOI https://doi.org/10.30525/978-9934-26-038-4-59

\title{
МІКРОБІОЛОГІЧНИЙ СКРИНІНГ ВЛАСТИВОСТЕЙ МАТЕРІАЛІВ НА ОСНОВІ БІОПОЛІМЕРІВ ТА АНТИСЕПТИКІВ
}

\author{
Назарчук О. А. \\ доктор медичних наук, \\ дочент кафедри мікробіологіі
}

Вінницький національний медичний університет імені М. І. Пирогова м. Вінниця, Украӥна

Грузевський О. А. кандидат медичних наук, дочент кафедри мікробіології, вірусологї̈ та імунології Одеський національний медичний університет м. Одеса, Украӥна

Дениско Т. В. асистент кафедри мікробіології, вірусології та імунології, Одеський національний медичний університет м. Одеса, Украӥна

Чорнопищук Р. М. кандидат медичних наук, асистент кафедри загальної хірургіі

Вінницький національний медичний університет імені М. I. Пирогова м. Вінниця, Украӥна

Кагляк М. Д. асистент кафедри мікробіології, вірусології та імунології Одеський національний медичний університет м. Одеса, Украӥна

Актуальність. Інфекції, пов'язані $з$ наданням медичної допомоги (ІПМД), спричиняють мікроорганізми, які володіють стійкістю до 
антимікробних препаратів. Зростаюча стійкість бактерій до антибіотиків викликає величезну стурбованість Всесвітньої організації охорони здоров'я. На шляху до вирішення даної глобальної проблеми дослідники різних галузей науки докладають значних зусиль в пошуку сучасних ефективних засобів боротьби зі збудниками інфекцій в місці безпосереднього ураження (рани, опіки). Науково-технічний прогрес, зокрема досягнення в галузі біології, медицини, в сучасному світі відзначився успіхами в розробці нових стратегій для досягнення швидкого загоєння ран і запобігання розвитку інфекційних ускладнень $[3,4,5]$. Розробка нових вдосконалених біоматеріалів, які здатні виділяти біомолекули і протимікробні препарати, належить до перспективних напрямків профілактики та лікування ранових інфекційних ускладнень $[1,2]$.

В умовах поширення антибіотикорезистентності мікроорганізмів набуває актуальності застосування антисептиків. Одним із найперспективніших вважають антисептик на основі четвертинних амонієвих сполук - декаметоксин [6]. Проблема локального створення тривалої концентрації антисептичного препарату повинна вирішуватись за рахунок вибору матриці, з якої буде вивільнюватись антимікробний засіб. Природні полімери (хітозан, колаген, еластин, альгінат, гіалуронова кислота, фібриноген) є біосумісними макромолекулами, які розпізнаються людським тілом [7].

Мета дослідження - провести скринінг зразків біоматеріалів на основі альгінату кальцію, полівінілового спирту та декаметоксину щодо їх антимікробних властивостей по відношенню до референтних та клінічних штамів мікроорганізмів.

Матеріали і методи. У дослідженні використовували референтні штами музею живих культур кафедри мікробіології Вінницького національного медичного університету ім. М. І. Пирогова Staphylococcus aureus ATCC 25923, Staphylococcus aureus ATCC 25927, Escherichia coli ATCC 25922, Escherichia coli ATCC 35213, Klebsiella pneumoniae ATCC 708603, Pseudomonas aeruginosa ATCC 27853, Acinetobacter baumannii ATCC BAA-747 та клінічні ізоляти Staphylococcus aureus $(\mathrm{n}=15)$, Acinetobacter baumannii $(\mathrm{n}=12)$, Pseudomonas aeruginosa $(\mathrm{n}=10)$, Escherichia coli $(\mathrm{n}=10)$, Klebsiella pneumoniae $(\mathrm{n}=8)$.

Досліджувані зразки, являли собою антимікробну композицію, що містила декаметоксин (0.03 мас. \% - зразок 1; 0.05 мас. \% - зразок 2; 0.07 мас. \% - зразок 3) та плівкоутворюючі біополімери альгінат кальцію 3 полівініловим спиртом у співвідношенні $2,3: 1$. Для проведення мікробіологічного дослідження з готових висушених плівкоподібних матеріалів (товщина 1 мм) в стерильних умовах готували диски діаметром 6 мм.

Дослідження чутливості штамів мікроорганізмів проводили дискодифузійним методом за загальноприйнятою методикою. Результати 
оцінювали через 24 год шляхом вимірювання діаметрів зон затримки росту (ДЗЗР) мікроорганізмів навколо дисків 3 точністю до 1 мм. В якості контролів використовували стандартні диски фільтрувального паперу, змочені розчинами декаметоксину $0.02 \%$ та хлоргексидину $0.05 \%$. Дослідження проводили не менше 10 разів щодо кожного із зазначених штамів мікроорганізмів.

Результати досліджень. Встановлено, що досліджувані зразки біоматеріалів на основі декаметоксину проявили високі антимікробні властивості щодо референтного та клінічних штамів A. baumannii, який $\epsilon$ широко розповсюдженим антибіотикорезистентним мікроорганізмом, що колонізує рани і віднесений ВООЗ до патогенів критичного рівня пріоритетності (ДЗЗР: від 9.50 мм до 13.00 мм). Їх протимікробна дія щодо деяких штамів A. baumannii достовірно перевищувала таку дію контрольних розчинів декаметоксину та хлоргексидину $(\mathrm{p}<0.05)$. Активність досліджуваних зразків була нижчою щодо референтних та клінічного штамів E. coli (ДЗЗР: від 8.20 мм до 9.70 мм). Дія антисептиків в контрольних розчинах та у складі полімерних біоматеріалів на референтні та клінічні штами K. pneumoniae (ДЗЗР: від 7.20 мм до 9.70 мм) та P. aeruginosa (ДЗ3Р: від 8.50 мм до 9.80 мм) була рівномірною, але достатньо ефективною. Найвищу протимікробну дію антимікробні полімерні композиції на основі декаметоксину, альгінату та полівінілового спирту, подібно до контрольних тест-об'єктів, насичених розчинами антисептиків, проявили щодо референтних та клінічних штамів $S$. aureus, що віднесений ВООЗ до патогенів високого рівня пріоритетності (ДЗЗР: від 11.50 мм до 17.40 мм).

Висновки. Зразки антимікробних біоматеріалів на основі природного полімеру альгінату кальцію та четвертинної амонієвої сполуки декаметоксину (0.03-0.07 мас. \%), проявляють високі антимікробні властивості щодо референтних та клінічних штамів $S$. aureus_та грамнегативних бактерій (A. baumannii, E. coli, K. pneumoniae, P. aeruginosa). Антимікробна активність зразків біоматеріалів щодо стафілокока (ДЗЗР: від 11.50 мм до 17.50 мм) перевищує дію на грамнегативні бактерії (Д33Р: від 7.200 мм до 13.00 мм). Зразки антимікробних біоматеріалів не поступаються протимікробній дії контрольному $0.02 \%$ розчину декаметоксину щодо музейних і клінічних штамів грампозитивних і грамнегативних мікроорганізмів ( $<<0.05-0.001)$.

Антимікробні біоматеріали на основі природного полімеру альгінату кальцію та полівінілового спирту являють собою депо-форми, здатні вивільняти концентрації антисептика декаметоксину ефективні щодо широкого спектру пріоритетних грампозитивних та грамнегативних збудників ранової інфекції. 


\section{Література:}

1. Штильман М. И. Биоматериалы - важное направление биомедицинских технологий. Вестник РГМУ. 2016. № 5. С. 4-14.

2. Martí, M., Frígols, B., Serrano-Aroca, A. Antimicrobial Characterization of Advanced Materials for Bioengineering Applications. J. Vis. Exp. (138), e57710, doi:10.3791/57710 (2018).

3. Custodio H.T., Hospital-Acquired Infections: Practice Essentials, Background, Pathophysiology. Medscape. 08.12.2016. https://emedicine.medscape.com/article/967022-overview

4. CDC. Antibiotic Resistance Threats in the United States, 2019. Atlanta

5. World Health Organisation. Antimicrobial Resistance: Global Report on Surveillance. Geneva, Switzerland: WHO Press; 2014.

6. Paliy GK, Nazarchuk OA, Bobyr VV Evaluation of antibacterial and antifungal properties of modern antiseptics. Microbiology and biotechnology. 2015. № 4(32). Pp. 67-74.

7. Mayet, N., Choonara, Y.E., et al., 2014. A comprehensive review of advanced biopolymeric wound healing systems. J. Pharm. Sci. № 103(8). P. 2211-2230. 